\title{
The Corpse Is a Silent Witness Who Never Lies-A Case Report
}

\author{
Vijay Pal1', Pawan Mittal1, Jitender K. Jakhar1', Yogesh Kumar Vashist'1, \\ A. D. Aggarwal'2, Bhavesh Bohra ${ }^{3}$ \\ ${ }^{1}$ Department of Forensic Medicine, Pt. B. D. Sharma PGIMS, Rohtak, \\ Pt. Bhagwat Dayal Sharma University of Health Sciences, Rohtak, India \\ ${ }^{2}$ Department of Forensic Medicine, Government Medical College, Patiala, India \\ ${ }^{3}$ Department of Forensic Medicine, Jhalawar Medical College, Jhalawar, India \\ Email: ${ }^{*}$ drvijaykhanagwal@yahoo.co.in
}

Received 14 May 2014; revised 16 June 2014; accepted 26 June 2014

Copyright (C) 2014 by authors and Scientific Research Publishing Inc.

This work is licensed under the Creative Commons Attribution International License (CC BY). http://creativecommons.org/licenses/by/4.0/

(c) (i) Open Access

\section{Abstract}

There are two very common sayings about corpse (dead body). The first common saying is that "the corpse is a silent witness who never lies" and the other common saying is that "the dead body is extremely eloquent and honestly informative, if one exercises patience in listening to it." Both these sayings were proved in one of our cases. In the present case, decomposed body of an unidentified female individual aged about 25 - 26 years was recovered from the bank of western Yamuna canal in Haryana. The police made the efforts for establishing the identity of the deceased but could not succeed. The body was forwarded to the district hospital for autopsy along with the inquest report. However, the body being in advanced stage of decomposition so it was referred from the district hospital to the department of Forensic Medicine, PGIMS, Rohtak (Haryana) for the examination and the expert opinion regarding the cause of death. The findings observed on examination of the body helped to deduce the cause, time and manner of death whereas certain important objective features of identification were also observed and ultimately proper identity of the deceased could be established beyond the reasonable doubt by DNA profile of the samples preserved at autopsy. The autopsy findings, DNA profile and the results of examination of other materials (exhibits) taken from the body not only revealed the truth from the silent witness-the corpse, but also provided objective and scientific evidence to establish the corpus delicti in this case.

\section{Keywords}

Corpus Delicti, Rape, Throttling, Murder, Putrefaction, DNA Profile

\footnotetext{
*Corresponding author.
}

How to cite this paper: Pal, V., Mittal, P., Jakhar, J.K., Vashist, Y.K., Aggarwal, A.D. and Bohra, B. (2014) The Corpse Is a Silent Witness Who Never Lies-A Case Report. Forensic Medicine and Anatomy Research, 2, 43-47. 


\section{Introduction}

Sex related homicides include rape-murders, serial murders, killings which involve both anal and oral sodomy, and other acts of sexual perversion as well as sexually oriented interpersonal violence cases. Rape-homicides are relatively uncommon. When they do occur, they are usually more vicious than routine homicides and generate more publicity and public outcry. They are often extremely difficult to solve because they frequently represent the purest form of stranger-to-stranger crime, that is, the victim and assailant are unknown to each other. There is usually only one assailant, so there is no one to "squeal" to the police. In addition, it is not the type of crime that most people brag about in bars. In rape-homicides, the cause of death is usually strangulation, stabbing, or blunt force injuries. Rape victims are rarely shot. Excessive force and unnecessary savagery are common in rape-homicides [1]. Although there is sexual element in the majority of the murders of women, over 75 percent of the killings occur during a domestic quarrel or are provoked by jealousy; in 10 - 20 percent is the murder prompted by the urge for sexual gratification [2].

A significant proportion of non-domestic homicides are associated with sexual offences, death occurring either because the woman rejects the sexual approaches or because a sadosexual motive colours an intended murder [3]. Unlike other murders, the motive or reason for the killing may not always be readily discernable or as "clear-cut" in sex related homicides, as is presented in a robbery-homicide, a drug related murder, or an organized crime "hit". Practically speaking, if the body is that of a female, and it is found nude or partially clothed, the investigator should think "sex crime" [4].

It is often seen to rape and murder the female victim and dispose of the body in a manner to conceal all the evidences constituting Corpus Delicti. The corpus delicti (the body of offence; the essence of crime) includes the identification of the body and facts conclusive of infliction of violence in a particular way, time and place. The case against the accused cannot be established unless there is convincing proof of these points [5]. However, proving these elements is not always so easy going. A dead body undergoes a series of changes, known as post mortem changes, after death. Prolonged postmortem interval invites decomposition that creates hindrance in the identification of the body and interpretation of injuries. Though the value of autopsy is progressively reduced as the state of putrefaction advances, no shortcuts should be taken by the pathologist merely because of unpleasant nature of examination [3].

A careful, detailed and meticulously performed autopsy emerges out with the findings that prove both the elements of corpus delicti and provides a start to the police in solving the crime. The present case is an illustration of the same facts in which the autopsy findings explanatory of identification along with the evidence of throttling in a young female shown the path to the police that in further conjunction with the circumstances and investigations of the case traced the assailant that emerged out with the facts related to rape homicide.

\section{Case History}

Dead body of a young adult female, aged about 25 - 26 years, was recovered from water (western Yamuna canal in Haryana (India) (Figure 1). The body was unidentified/unclaimed and in advanced stage of decomposition (Figure 2 and Figure 3). Efforts were made for establishing the identity of the deceased but were unsuc-

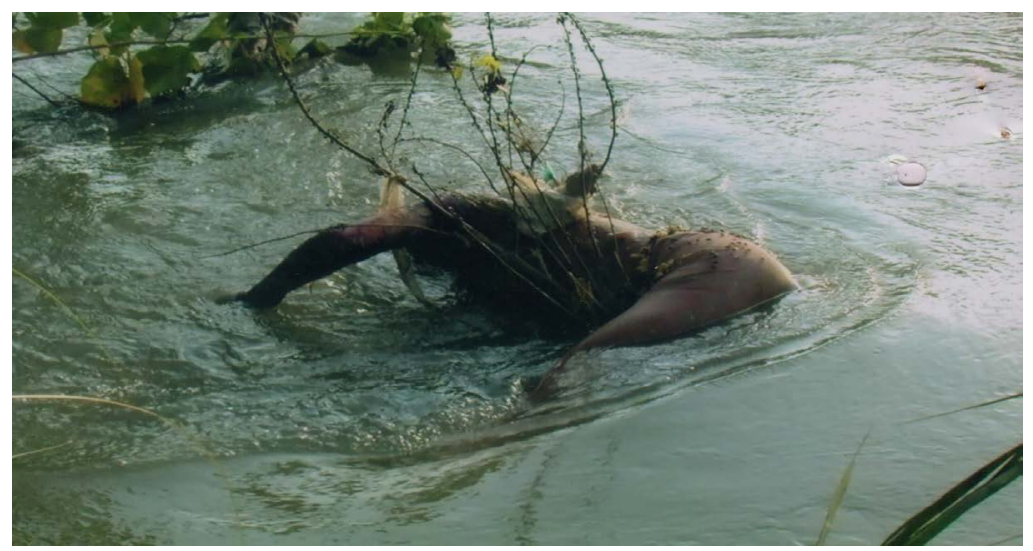

Figure 1. Body recovered from canal (lying in water). 


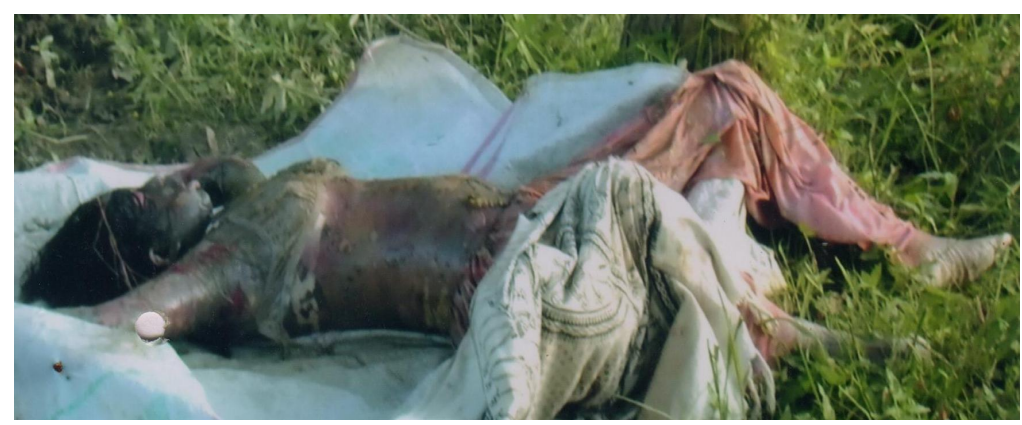

Figure 2. Body taken out of water (decomposed body).

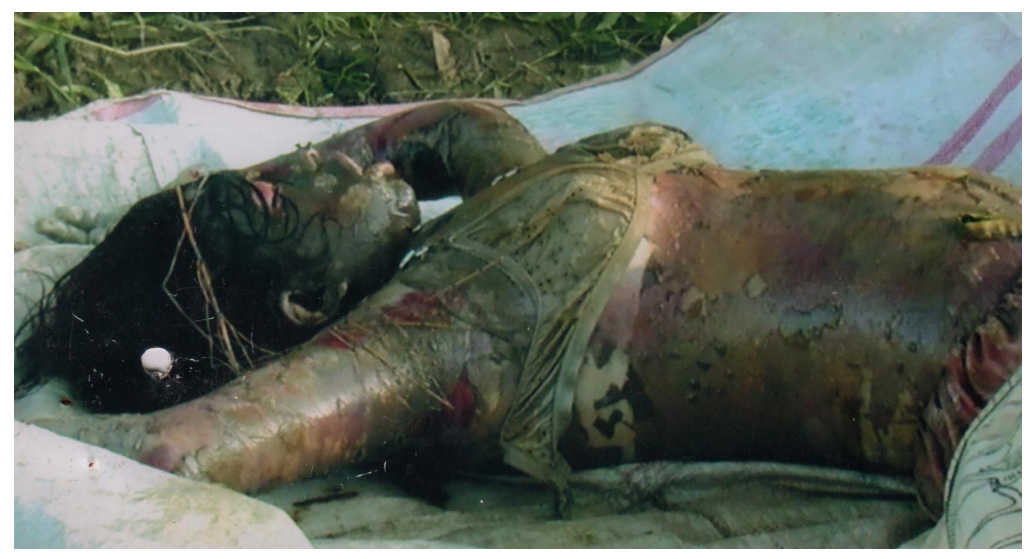

Figure 3. Close-up photograph of the body showing decomposition.

cessful. The dead body was forwarded to the nearest authorized District Hospital for conducting the autopsy by a board of doctors. Since the body had been recovered from water (canal), the apparent cause of death reported by the police was "drowning”. Meanwhile, a family from nearby village claimed that the dead body could be of their daughter-in-law, "Pinky” (fictitious name) who was missing from their house for the last 2 days. Simultaneously, they adopted a guarded approach in identifying the body. As the only means of identification of the body were the clothes (white brassiere, pinkish printed salwar having white and yellow floral designs) the family didn't claim it to be their own with certainty as the facial features were distorted on account of decomposition. The alleged in-laws were reluctant for taking the body to higher center and they pleaded for autopsy of the body at District Hospital only. But when their request was not acceded by the Medical Officers, the relatives bluntly refused to accompany the body and straightforwardly refused to claim it to be their own. The Medical Officers of District Hospital referred the body to our department with the remarks that the body being in decomposed state, required examination by an expert to ascertain cause, manner and time since death, and to provide data for its identification. Thus, ultimately the police had to bring the body to our department as an unclaimed/unidentified body.

\section{Autopsy Findings}

Length of the body was $166 \mathrm{~cm}$. The body was wearing only a white brassiere, pinkish printed salwar and four red glass bangles around right wrist. Scalp hair was 35 - $45 \mathrm{~cm}$ long and loosened. The body was in moderate stage of decomposition with bloating of facial features which were not identifiable.

As the leading findings of identification, the body was showing mild lordosis, linea albicantes over flanks and upper portion of thighs, old healed scar over abdomen suggestive of surgical operation. Dentition and skeletal changes (ossification of bones) being consistent with the stated age (about 25 - 26 years) of deceased. The skull was peculiar in appearance being unusually elongated in sagittal plane with the frontal and occipital prominences being very prominent and pointed (Peruvian) (Figure 4).

All these peculiarities though were sufficient to establish the identity of the body, yet a bone (clavicle) was 


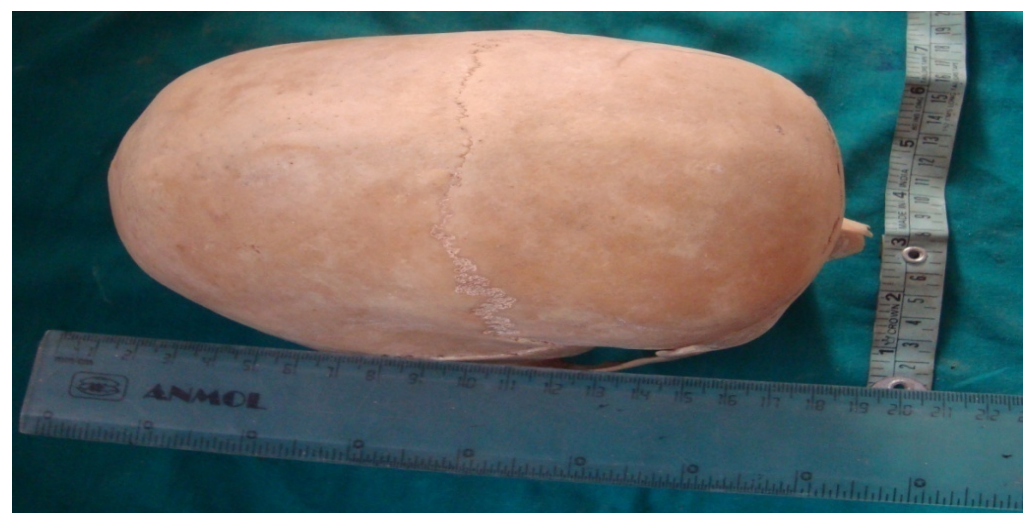

Figure 4. Peculiarity of skull (Peruvian).

also preserved for DNA profiling to prove absolute identification.

\section{Injuries Noticed over the Body}

Multiple reddish contusions were present over the front and sides of neck with marked ecchymosis of the underlying neck structures including larynx, trachea and thyroid and cricoid cartilages. Though the neck injuries were sufficient to establish the cause of death as throttling, yet sternum and clavicle were submitted for diatom test to rule out drowning of the unconscious (as had also been requested by Police). However, diatoms could not be detected in them.

Finally, the cause of death was opined to be throttling. Since it was a case of murder of a young female, vaginal swab and smears were preserved for detection of spermatozoa with a view to corroborate possibility of sexual assault as motive for the murder.

Diatoms could not be detected in the samples of sternum and clavicle. Human semen (spermatozoa) mixed with blood was detected on the vaginal swab and smear.

\section{Establishment of Identity/Corpus Delicti}

With a view to confirm the peculiarities regarding identification features noticed, the Investigating Officer approached the parents of deceased and after being convinced that the body could be of "Pinky" only, persuaded them (parents) to provide their blood sample for DNA testing. The parents readily gave their blood sample for DNA testing and comparison thereof with the DNA of deceased. DNA test performed on the exhibits was sufficient to conclude that the source of the clavicle (of deceased, "Pinky") was from the biological daughter of the source of exhibit (blood sample) of (name of father of the deceased, "Pinky"). Thus the identification of the corpse was established through autopsy and scientific investigations. The victim was none other than "Pinky", the daughter-in-law of the family which had earlier claimed and later refused it to be their own. Now the police had to trace the assailant. It did not take very long to reach the culprit.

Further investigation revealed the culprit to be the father-in-law of the deceased who made confession before the police that he was obsessed with the beauty of his daughter-in-law, "Pinky", and wanted to have sexual relationship with her but when she resisted against it, he raped her when the husband was away from home for his duty in military service. He further confessed that for the fear of disclosure of his misdeed, he throttled her and in order to conceal the crime he along with an accomplice disposed off the body in the canal at midnight on the fateful day.

\section{Conclusions}

The findings observed on autopsy helped to deduce the cause of death, manner of death, the time since death, leading points to identification (though the absolute identification of the deceased was established by DNA profile). Detection of spermatozoa on vaginal swab and smears proved sexual assault which was the motive for murder.

"The corpse is a silent witness who never lies" may be recalled as an aptly phrase in the present case. The ac- 
cused (live person) misled the investigating agency by telling lies but the "corpse told its own story albeit silently" providing objective and scientific evidence to establish the truth and further proved that "the dead body is extremely eloquent and honestly informative, if one exercises patience in listening to it".

\section{References}

[1] DiMaio, V.J. and DiMaio, D. (2001) Forensic Pathology. 2nd Edition, CRC Press, London, 452.

[2] Polson, C.J., Gee, D.J. and Knight, B. (1985) The Essentials of Forensic Medicine. 4th Edition, Oxford Pergamon Press, Oxford, 485.

[3] Saukko, P. and Knight, B. (2004) Knight’s Forensic Pathology. 3rd Edition, Oxford University Press Inc., London, 39-40, 421.

[4] Geberth, V.J. (1996) Practical Homicide Investigation: Tactics, Procedures, and Forensic Techniques. 3rd Edition, CRC Press, Inc., Boca Raton.

[5] Reddy, K.S.N. (2013) The Essentials of Forensic Medicine and Toxicology. 32nd Edition, Om Sai Graphics, Hyderabad, 56 . 